\title{
Bats from Fazenda Intervales, Southeastern Brazil - species account and comparison between different sampling methods
}

\author{
Christine V. Portfors 1 \\ M. Brock Fenton 2 \\ Ludmilla M. de S. Aguiar ${ }^{3}$ \\ Julio E. Baumgarten 4 \\ Maarten J. Vonhof 2 \\ Sylvie Bouchard ${ }^{2}$ \\ Deborah M. de Faria ${ }^{4}$ \\ Wagner A. Pedro ${ }^{5}$ \\ Naas I. L. Rauntenbach
Marlon Zortéa $^{7}$
}

\begin{abstract}
Assessing the composition of an area's bat fauna is typically accomplished by using captures or by monitoring echolocation calls with bat detectors. The two methods may not provide the same data regarding species composition. Mist nets and harp traps may be biased towards sampling low flying species, and bat detectors biased towards detecting high intensity echolocators. A comparison of the bat fauna of Fazenda Intervales, southeastern Brazil, as revealed by mist nets and harp trap captures, checking roosts and by monitoring echolocation calls of flying bats illustrates this point. A total of 17 species of bats was sampled. Fourteen bat species were captured and the echolocation calls of 12 species were recorded, three of them not revealed by mist nets or harp traps. The different sampling methods provided different pictures of the bat fauna. Phyllostomid bats dominated the catches in mist nets, but in the field their echolocation calls were never detected. No single sampling approach provided a complete assessment of the bat fauna in the study area. In general, bats producing low intensity echolocation calls, such as phyllostomids, are more easily assessed by netting, and bats producing high intensity echolocation calls are better surveyed by bat detectors. The results demonstrate that a combined and varied approach to sampling is required for a complete assessment of the bat fauna of an area.

KEY WORDS. Atlantic rain forest, bats, bat detector, chiroptera, diversity, echolocation, sampling methods, southeastern Brazil
\end{abstract}

1) Department of Neurobiology, Northeastern Ohio Universities College of Medicine. 4209, State Route 44, P.O. Box 95, Rootstown, Ohio 44272-0095, USA.

2) Corresponding author: Department of Biology, York University. North York, Ontario, M3J 1P3, Canada. E-mail: bfenton@yorku.ca

3) Departamento de Ecologia, Universidade de Brasilia. Caixa Postal 04474, 70919-970 Brasília, Distrito Federal, Brasil.

4) Departamento de Zoologia, Universidade Estadual de Campinas. Caixa Postal 6109, 13083-970 Campinas, São Paulo, Brasil.

5) Departamento de Apoio, Produção e Saúde Animal, Universidade Estadual Paulista. Caixa Postal 341, 16050-680 Araçatuba, São Paulo, Brasil.

6) Transvaal Museum, P.O. Box 413, Pretoria, South Africa.

7) Programa de Pós-graduação em Ecologia e Recursos Naturais, Universidade Federal de São Carlos. Caixa Postal 676, 13565-905 São Carlos, São Paulo, Brasil. 
In many parts of the world bats are an important component of mammalian diversity. This is especially true in the tropics and subtropics where the number of species increases dramatically (WILSON 1974) and both density and species diversity are the highest (FINDLEY 1993). Captures are the traditional means of assessing the composition of an area's bat fauna, typically through the use of shooting, mist nets and traps, and sampling focused around known roost sites (VOSS \& EMMONS 1996; Simmons \& Voss 1998). The use of bat detectors to monitor the species-specific echolocations calls (FENTON \& Bell 1981; O'FARREL \& Miller 1997) is another method of documenting the bat fauna of an area, but one that may not provide the same picture of the fauna as captures (FENTON et al. 1987; GANNON \& SEXTON 1996; RAUTENBACH et al. 1996).

While some authors specifically state that bat detectors are not useful in some situations (BROSSET et al. 1996), others have used them extensively to document distribution (BAGGOE 1987) and habitat use (VAUGHAN et al. 1996; WALSH \& HARRIS 1996) or responses to feeding opportunities (RYDELL \& RACEY 1995). Just as mist nets may reliably sample some species and not others (VOSS \& EMMONS 1996), variability in the intensity of echolocation calls affects the efficacy of bat detectors (FENTON \& BELL 1981; WATERS \& JONES 1995).

The purpose of this study was to inventory the bat fauna of an area as revealed by captures, with mist nets and harp traps, and by monitoring echolocation calls with bat detectors. The bat fauna was sampled at a variety of habitats and at known roosts (caves and buildings). It was expected that the two methods of sampling would provide different results, and predict that this study will reinforce the idea that using different sampling techniques provides the most accurate picture of the composition of bat fauna in an area.

\section{MATERIAL AND METHODS}

Bats were sampled, between 4 and 14 January 1997, in sites around the Fazenda Intervales, a Field Research Station located in the state of São Paulo, in southeastern Brazil ( $\left.24^{\circ} 16^{\prime} \mathrm{S}, 48^{\circ} 24^{\prime} \mathrm{W}\right)$. In this area, the vegetation is Atlantic rain forest (pluvial or rain forest). The Fazenda Intervales station is located in an area of karst where limestome caves provide abundant roosts for bats. There is no distinct dry season in the area, although precipitation is lower between May and September than at other times of the year (TRAJANO 1996). The annual rainfall ranges between 1000 and $2000 \mathrm{~mm}$, and the mean annual temperature is about $20^{\circ} \mathrm{C}$.

On seven nights mist nets, harp traps and bat detectors were used to sample the bat fauna in a variety of forest and edge habitats, at least $500 \mathrm{~m}$ from known roosts. Six or $12 \mathrm{~m}$ long mist nets were opened for varying periods of time. Bat echolocation calls were simultaneously monitored, in the same sites, with Anabat bat detectors coupled with Anabat ZCA modules and Anabat 5 software loaded on laptop computers. Anabat files of echolocation calls were saved and analyzed in the laboratory to assess the variety of bat calls. On two nights $6 \mathrm{~m}$ long mist nets and a harp trap (TUTTLE 1974) were used to sample bats emerging from caves or building roosts. 
Mist nets were set at heights ranging from $0.2 \mathrm{~m}$ to $3.0 \mathrm{~m}$ above the ground. The nets were tended continuously while they were open. For each captured bat the forearm length (to the nearest $\mathrm{mm}$ ), mass (to the nearest $0.5 \mathrm{~g}$ ) and time of capture were recorded. Most bats were identified at the time of capture and released, but some voucher specimens were taken for later confirmation of their identities. To obtain Anabat files of the echolocation calls of known species of bats, both light tagging (HovorkA et al. 1996) and recordings of the echolocation calls of some captive bats, as they flew in a 4 by $5 \mathrm{~m}$ laboratory, were used.

\section{RESULTS AND DISCUSSION}

A total of 123 captured bats of 14 species were sampled. Five species of bats were caught at the entrances to roosts (cave: two species; building: three species), and 10 species in mist netting, away from roosts, in forested habitats (Tab. I). Seven species were detected by their echolocation calls (Tab. I).

Based on the echolocation calls of the species caught and light-tagged, three species could be positively identified (Tab. I). A total of 18 bat species was detected by both sampling methods. Expressed as rates of capture (Tab. I), the data show that sampling at roosts and monitoring echolocation calls provided the highest rates encounters with bats.

Table I. A comparison of the bats of Fazenda Intervales station, southeastern Brazil, as revealed by captures in mist nets, sampling at roosts and monitoring echolocation calls.

\begin{tabular}{|c|c|c|c|c|c|}
\hline Species & $\mathrm{N}$ & $\begin{array}{l}\text { Mist netting in } \\
\text { forested habitats }\end{array}$ & Sampling at roosts & $\begin{array}{c}\text { Echolocation } \\
\mathrm{KHz}\end{array}$ & $\begin{array}{l}n \text { calls } \\
\text { ms }\end{array}$ \\
\hline Peropteryx macrotis (Wagner 1843) & 7 & - & $7(B)$ & $36-38$ & 10 \\
\hline Micronycteris megalotis (Gray 1842) & 1 & 1 & - & $59-94$ & $1-2^{*}$ \\
\hline Lonchorrhina aurita Tomes, 1863 & 2 & 2 & - & - & - \\
\hline Anoura caudifera (Geoffroyi, 1818) & 3 & 3 & - & - & - \\
\hline Carollia perspicillata (Linnaeus, 1758) & 12 & 12 & - & $56-90$ & $1-2^{*}$ \\
\hline Sturnira lilium (E. Geoffroy, 1810) & 59 & 59 & - & $57-86$ & $1-2$ * \\
\hline Platyrrhinus lineatus ( $E$. Geoffroy, 1810) & 1 & 1 & - & - & - \\
\hline Artibeus lituratus (Olfers, 1818) & 2 & 2 & - & - & - \\
\hline Artibeus fimbriatus Gray, 1838 & 2 & 2 & - & - & - \\
\hline Desmodus rotundus (E.Geoffroyi, 1810) & 1 & 1 & - & 48-74 & $1-2$ \\
\hline Furipterus horrens (F. Cuvier, 1828) & 1 & - & $1(\mathrm{~B})$ & $120-150$ & $<1$ \\
\hline Myotis nigricans (Schinz, 1821) & - & - & - & 58-65 & 5 \\
\hline Myotis aff. riparius Handley, 1960 & 5 & 4 & $1(\mathrm{~A})$ & $50-58$ & 4 \\
\hline Histiotus velatus (I. Geoffroy, 1824) & 16 & - & $16(A)$ & $15-25$ & $5-8$ \\
\hline Eptesicus brasiliensis (Desmarest, 1819) & - & - & - & $42-54$ & $5-10$ \\
\hline Lasiurus blossevillii Lesson \& Ganot, 1826 & - & - & - & $35-49$ & $5-8$ \\
\hline Tadarida brasiliensis (1. Geoffroy, 1824) & 11 & - & 11 (A) & $26-38$ & 12 \\
\hline Total & 123 & 87 & 36 & - & - \\
\hline
\end{tabular}

$\left.{ }^{*}\right)$ Recorded from individuals flying in a room: (A) building, with mist nets, (B) cave, with harp trap.

The different approaches to sampling bats gave different pictures of the bat fauna of the study area (Tab. I). While phyllostomid bats dominated the catches in mist nets, their low intensity echolocation calls meant that they were not detected at all when using echolocation calls as indicators of bat activity. No single sampling method provided a complete picture of the bats of the study area. General captures 
in mist nets suggested that Sturnira lilium (E. Geoffroy, 1810) dominated the chiropteran fauna, whereas the incidences of echolocation calls suggested that Histiotus velatus (I. Geoffroy, 1824), Tadarida brasiliensis (I. Geoffroy, 1824), and Eptesicus brasiliensis (Desmarest, 1819) were most common in the sampling area.

Bats are among the least known of mammals whether the topic is general patterns of distribution, details of habitat use or information about their roosts (FENTON 1997). The data demonstrated here show the importance of using a combined approach to effectively assess the bat fauna of an area. The suggestion that bat detectors are of little use in surveys of bats (BROSSET et al. 1996) and ignoring them as sampling tools (Voss \& EMMONS 1996) is as unrealistic as expecting them to completely replace the more traditional capture-based techniques.

Indeed, some evidence suggests that general levels of bat traffic, as indicated by monitoring echolocation calls, are more predictably associated with insect activity than are captures in mist nets (RAUNTENBACH et al. 1996).

Based on the frequency and time features of the echolocation calls and information about the bats known from the study area, three species of bats were associated with echolocation calls recorded (Tab. I). Specifically, it was expected that Eptesicus brasiliensis (Desmarest, 1819), produced the calls sweeping from 54 to $42 \mathrm{kHz}$ in 5-10 ms, Myotis nigricans (Schinz, 1821) the calls sweeping from $65-58 \mathrm{kHz}$ in $5 \mathrm{~ms}$, and Lasiurus blossevillii Lesson \& Ganot, 1826, the calls sweeping from 49 to $35 \mathrm{kHz}$ in $5-8 \mathrm{~ms}$. The echolocation calls associated elsewhere with Lasiurus ega (Gervais, 1856) (35 to $28 \mathrm{kHz}$ ) in 10-15 ms; (J. Rydell personal communication) or the distinctive calls associated with either species of Noctilio Linnaeus 1766, (ROVERUD \& GRINNELl 1985), that occur in the study area or vicinity (D.G. Manço personal communication), were not recorded. Also missing from the obtained sample were the longer, narrowband calls of lower frequency $(<$ $25 \mathrm{kHz}$ ) associated with other species of molossids (RYDELL \& ARLETTAZ 1994).

Previous study of bats in the Fazenda Intervales station area reported 24 species (D.G. Manço personal communication), including many that were not caught in this survey (13 species: Phyllostomus hastatus (Pallas, 1767), Tonatia bidens (Spix, 1823), Trachops cirrhosus (Spix, 1823), Anoura geoffroyi Gray 1838, Glossophaga soricina (Pallas, 1766), Artibeus obscurus Schinz, 1821, Pygoderma bilabiatum (Wagner, 1843), Sturnira tildae de la Torre, 1959, Diphylla ecaudata Spix, 1823, Eptesicus brasiliensis, Lasiurus blossevillii, Lasiurus ega and Myotis nigricans. One Myotis ruber (E. Geoffroy, 1806), a species reported to occur by D.G. Manço (personal communication), was caught, but its capture did not occur during the paired sampling sessions reported here. If the tentative identifications of species by their calls are correct, then by using both capture and monitoring echolocation calls, 18 of the 29 species known from the area were detected. The sample here considered accounted for nine of 19 phyllostomids known from the area, the single species of furipterid, emballonurid and molossid, as well as five of the seven vespertilionids. Generally speaking, low intensity echolocators such as phyllostomids are more easily detected by netting and high intensity echolocators may be more conspicuous by their echolocation calls. 
Variation in the intensity of echolocation calls emitted by microchiropteran bats has been well known for years (GRIFFIN 1958), and yet it is still a lack of accurate data on call intensity for most species (WATERS \& JONES 1995). In this study, the phyllostomids produced low intensity echolocation calls as predicted from previous work (Novick 1977), as did the furipterid, Furipterus horrens (F. Cuvier, 1828), whose calls were previously unknown.

The study of bats in the field requires a combined and varied approach. In the last four years both specimen-based (SIMMONS 1996) and echolocation-based research (JONES \& VAN PARIJS 1993) have increased the knowledge of the biodiversity of bats, in a local and global perspective.

ACKNOWLEDGEMENTS. We thank E. Trajano for making the arrangements for working at Fazenda Intervales. R.M. Brigham, D.A. Blankenship, C.D. Grose and E.R. Dumont for reading earlier drafts of this manuscript and making suggestions for its improvement. This study was supported by a Natural Sciences and Engineering Research Council of Canada research grant to MBF.

\section{REFERENCES}

BAGGOE, H.J. 1987. The Scandinavian bat fauna: adaptative wing morphology and free flight in the field, p. 57-74. In: M.B. FENTON; P.A. RACEY \& J.M.V. RAYNER (Eds). Recent advances in the study of bats. Cambridge, Cambridge University Press, 470p.

Brosset, A.; P. Chırles-Dominique; A. Cockle; J-F. Cosson \& D. MAsson. 1996. Bat communities and deforestation in French Guiana. Canadian Jour. Zool. 74: 1974-1982.

FEnTON, M.B. 1997. Science and the conservation of bats. Jour. Mammal. 78: 1-14.

FEnTON, M.B.; D.C. TENNANT \& J. WySZECKI. 1987. Using echolocation calls to measure the distribution of bats: the case of Euderma maculatum. Jour. Mammal. 68: 142-144.

Fenton, M.B. \& G.P. BELL. 1981. Recognition of the species of bats by their echolocation calls. Jour. Mammal. 62: 233-243.

FINDLEY, J.S. 1993. Bats: a community perspective. Cambridge University Press, Cambridge, 167p.

GANNON, W.L. \& J.P. SEXTon. 1996. Evaluation of bat diversity in New Mexico using the Anabat detector. Bat Research News 37: 132-133.

GrifFIN, D.R. 1958. Listening in the dark. New Haven, Yale University Press, 415p.

Hovorka, M.D.; C.S. MARKS \& E. MuLLER. 1996. An improved chemiluminescent tag for bats. Wildlife Soc. Bull. 24: 709-712.

JONES, G. \& S.M. VAN PARIJS. 1993. Bimodal echolocation in pipistrelle bats: are cryptic species present?

Proc. Royal Soc. London, Biological Sciences, 251: 119-125.

Novick, A. 1977. Acoustic orientation, p. 74-289. In: W.A. WIMSATT (Ed.). Biology of Bats. New York, Academic Press, Vol. 3, 651p.

O'FARREL, M.J. \& B.W. MiLler. 1997. A new examination of echolocation calls of some Neotropical bats (Emballonuridae and Mormoopidae) using Anabat. Jour. Mammal. 78 (3): 954-963.

RAUTENBACII, I.L.; M.B. Fenton \& M.J. Wiliting. 1996. Bats in riverine forests and woodlands: a longitudinal transect in southern Africa. Canadian Jour. Zool. 74: 312-322.

ROVERUD, R.C. \& A.D. GRINNELL. 1985. Discrimination performance and echolocation signal integration requirements for target discrimination and distance determination in the CF/FM bat, Noctilio albiventris. Jour. Comp. Physiol. 156: 447-456.

RYDELL, J. \& P.A. RACEY. 1995. Streetlamps and the feeding ecology of insectivorous bats. Symp. Zool. Soc. London 67: 291-308.

RYDELL, J. \& R. ARLETTAZ. 1994. Low-frequency echolocation enables the bat Tadarida teniotis to feed on tympanate insects. Proc. Royal Soc. London 257: 175-178. 
Sımmons, N.B. 1996. A new species of Micronycteris (Chiroptera: Phyllostomidae) from northeastern

Brazil, with comments on phylogenetic relationships. Amer. Mus. Novit. 3158: 1-34.

Simmons, N.B. \& R.S. Voss. 1998. The mammals of Paracou, French Guiana: a neotropical lowland rainforest fauna. Part 1. Bats. Bull. Amer. Mus. Nat. His. 237: 1-219.

Trajano, E. 1996. Movements of cave bats in southeastern Brazil, with emphasis on the population ecology of the common vampire bat, Desmodus rotundus (Chiroptera). Biotropica 28: 121-129.

TUTTLE, M. D. 1974. An improved trap for bats. Jour. Mammal. 55: 475-477.

VAUGHAN, N.; G. JONES \& S. HARRIS. 1996. Effect of sewage effluent on the activity of bats (Chiroptera: Vespertilionidae) foraging along the rivers. Biol. Conserv. 78: 337-343.

Voss, R.S. \& L.H. Emmons. 1996. Mammalian diversity in Neotropical lowland rainforests: a preliminary assessment. Bull. Amer. Mus. Nat. Hist. 230: 1-115.

WALSH, A.L. \& S. HaRRIS. 1996. Factors determining the abundance of vespertilionid bats in Britain: geographical, land class and local habitat relationships. Jour. Appl. Ecol. 33: 519-529.

WATERS, D.A. \& G. JONES. 1995. Echolocation call structure and intensity in five species of insectivorous bats. Jour. Experim. Biol. 198: 475-489.

WiLson, J.W. 1974. Analytical zoogeography of North American mammals. Evolution 28: 124-140.

Recebido em 10.VI.199; aceito em 09.V.2000

Revta bras. Zool. 17 (2): 533 - 538, 2000 